\title{
FINANCIAL DISTRESS DIPENGARUHI OLEH SALES GROWTH DAN INTELLECTUAL CAPITAL
}

\author{
Eka Rima Prasetya *, Rakhmawati Oktavianna \\ Universitas Pamulang, Tangeran Selatan, Indonesia \\ *Email: ekarima@unpam.ac.id
}

\begin{abstract}
This study was conducted to examine the effect of sales growth and intellectual capital on financial distress in manufacturing companies listed on the Indonesia Stock Exchange (IDX) in 2014 - 2019. The type of research in this study uses a quantitative approach. Data collection uses the document method with secondary data sources. Determination of the sample using the purposive sampling method, with a total sample of 84 samples. The data analysis technique used is multiple linear regression using the Eviews 10 program. The results of this study are that sales growth and intellectual capital together have an effect on financial distress, sales growth has no effect on financial distress and intellectual capital has an effect on financial distress.
\end{abstract}

Keywords: financial distress; sales growth; intellectual capital

\begin{abstract}
ABSTRAK
Penelitian ini dilakukan untuk menguji pengaruh pertumbuhan penjualan dan modal intelektual terhadap financial distress pada perusahaan manufaktur yang terdaftar di Bursa Efek Indonesia (BEI) tahun 2014 - 2019. Jenis penelitian dalam penelitian ini menggunakan pendekatan kuantitatif. Pengumpulan data menggunakan metode dokumen dengan sumber data sekunder. Penentuan sampel menggunakan metode purposive sampling, dengan jumlah sampel sebanyak 84 sampel. Teknik analisis data yang digunakan adalah regresi linier berganda dengan menggunakan program Eviews 10. Hasil penelitian ini adalah pertumbuhan penjualan dan modal intelektual secara bersama-sama berpengaruh terhadap financial distress, pertumbuhan penjualan tidak berpengaruh terhadap financial distress dan modal intelektual berpengaruh terhadap financial distress.
\end{abstract}

Kata kunci: kesulitan keuangan; pertumbuhan penjualan; modal intelektual

\section{PENDAHULUAN}

Kondisi perekonomian di Indonesia saat ini sedang memasuki masa krisis, di mana kondisi ini sangat rawan terhadap terjadinya kesulitan keuangan (financial

* Corresponding author's e-mail: ekarima@unpam.ac.id

http://openjournal.unpam.ac.id/index.php/JABI 
Jurnal Akuntansi Berkelanjutan Indonesia - Vol. 4, No. 2, Mei 2021 - Prasetya \& Oktavianna

distress) pada beberapa Perusahaan Nasional. Pada tahun 2018, Salah satu perusahaan besar di Indonesia yang dinyatakan pailit pada tahun 2018 adalah PT Sariwangi Agricultural Estate Agency (SAEA) bersama perusahaan afiliasinya PT Maskapai Perkebunan Indorub Sumber Wadung (MPISW). Kepailitan yang dialami kedua perusahaan tersebut disebabkan karena terjeratnya hutang yang mencapai Rp 1,5 triliun kepada sejumlah kreditur. Timbulnya hutang tersebut dikarenakan kedua perusahaan gagal berinvestasi untuk meningkatkan produksi perkebunan. Selain itu, pembayaran hutang yang tersendat menyebabkan sejumlah kreditur mengajukan tagihan. Namun, dikarenakan SAEA dan MPISW tidak sanggup membayar cicilan tersebut, maka pada 17 Oktober 2018, Majelis Hakim Pengadilan Niaga Jakarta Pusat mengabulkan permohonan pembatalan homologasi dari salahsatu kreditur, yaitu PT Bank ICBC Indonesia terhadap SAEA dan MPISW (Sumber: https://ekonomi.kompas.com).

Pendanaan yang dilakukan perusahaan dalam bentuk hutang ini akan menimbulkan kewajiban bagi perusahaan untuk melunasi hutang tersebut. Jumlah hutang yang semakin tinggi akan mengakibatkan bunga yang ditanggung semakin tinggi (Rohmadini et al., 2018). Kebijakan utang perusahaan merupakan kebijakan yang diambil oleh pihak manajemen dalam rangka memperoleh sumber pendanaan dari pihak ketiga untuk membiayai aktivitas operasional perusahaan. Menurut Harmono (2011:137) dalam safitri (2020). Jika perusahaan tidak mampu membayar hutang yang dimilikinya maka kegiatan operasional perusahaan dapat terganggu sehingga pendapatan perusahaan berkurang. Kondisi ini dapat memicu terjadinya financial distress. Financial distress dapat diakibatkan oleh beberapa penyebab. Menurut Hadi (2014) financial distress dapat timbul dengan adanya faktor dari internal dan ekternal perusahaan. Faktor internal perusahaan meliputi: kesulitan arus kas, besarnya jumlah hutang, dan kerugian yang terjadi dari kegiatan operasi tidak memenuhi persyaratan pencatatan, maka saham tersebut dapat dikeluarkan dari pencatatan di Bursa Efek.

Menurut Harahap (2013:309), rasio pertumbuhan menggambarkan persentase pertumbuhan pos-pos perusahaan dari tahun ke tahun. Rasio pertumbuhan penjualan (sales growth) merupakan cerminan dari kinerja manajemen suatu perusahaan untuk dapat meningkatkan penjualan dari satu periode. Menurut Whidiari Merkusiwati (2015:467) dalam penelitiannya menunjukkan hasil bahwa Sales Growth berpengaruh negative dan signifikan terhadap Financial Distress. Hal tersebut dikarenakan nilai sales growth yang rendah menggambarkan kemampuan perusahaan di dalam menciptakan penjualan semakin turun yang akan mempengaruhi kondisi Financial Distres perusahaan.

Modal intelektual (Intellectual Capital) sendiri berperan penting dalam menciptakan nilai tambah (value added) bagi perusahaan yang nantinya akan meningkatkan kinerja perusahaan untuk dapat memberikan keunggulan bersaing dari suatu perusahaan. penelitian yang dilakukan oleh Puspitasari dan Srimindarti (2014) yang meneliti mengenai peran intellectual capital terhadap kinerja perusahaan. Hasil penelitian menunjukkan bahwa intellectual capital berpengaruh positif dan signifikan terhadap kinerja perusahaan. Adanya pengelolaan intellectual

* Corresponding author's e-mail: ekarima@unpam.ac.id 
Jurnal Akuntansi Berkelanjutan Indonesia - Vol. 4, No. 2, Mei 2021 - Prasetya \& Oktavianna

capital yang baik akan meningkatkan kinerja perusahaan. Peningkatan kinerja perusahaan mengindikasikan perusahaan dalam keadaan sehat dan tidak mengalami financial distress.

\section{LANDASAN TEORI}

Brigham dan Hauston isyarat (2001) dalam ( Maihafni,2016) signal adalah suatu tindakan yang diambil perusahaan untuk memberi petunjuk bagi investor tentang bagaimana manajemen memandang prospek perusahaan. Eksekutif perusahaan dengan informasi yang lebih baik tentang perusahaannya akan terdorong untuk menyampaikan informasi tersebut kepada calon investor dimana perusahaan dapat meningkatkan nilai perusahaan melalui pelaporannya dengan mengirimkan sinyal melalui laporan tahunannya, (Irawati, 2018). Financial distress menjadi sinyal bagi para investor dalam mengambil keputusan investasi. Telah sejak lama berbagai literatur finansial menggambarkan financial distress sebagai sebuah kondisi yang merugikan di mana kemungkinan terjadinya hal ini sangat penting dalam menentukan struktur modal perusahaan yang optimal.

Hanifah (2013) financial distress didefinisikan sebagai tahap penurunan kondisi keuangan yang terjadi sebelum terjadinya kebangkrutan ataupun likuidasi. Hidayat (2013) menyatakan bahwa suatu perusahaan dapat dikatakan berada dalam kondisi financial distress apabila perusahaan tersebut mempunyai laba bersih (net profit) negatif selama beberapa tahun. Hapsari (2012), financial distress adalah suatu kondisi di mana arus kas operasi suatu perusahaan tidak memadai untuk melunasi kewajiban-kewajiban lancar (seperti hutang dagang atau beban bunga) dan perusahaan tersebut terpaksa melakukan tindakan perbaikan.

$\mathrm{Ni}$ Luh dkk (2015), pertumbuhan penjualan dalam suatu perusahaan mencerminkan adanya keberhasilan investasi pada masa lalu dan dapat dijadikan prediksi di masa yang akan datang. Rahmy (2015:10) Pertumbuhan penjualan (sales growth) adalah rasio yang menggambarkan kemampuan perusahaan dalam meningkatkan penjualannya dari tahun ke tahun. Semakin tinggi tingkat Sales Growth suatu perusahaan maka perusahaan tersebut dinilai berhasil dalam menjalankan strateginya dalam hal penjualan produk maupun pemasaran.

Modal intelektual (Intellectual Capital) seringkali menjadi faktor penentu utama perolehan laba suatu perusahaan. Menurut Stewart (1997) adalah sebuah konsep modal yang merujuk pada modal tidak berwujud yang terkait dengan pengetahuan dan pengalaman manusia serta teknologi yang digunakan. Aset tak berwujud tersebut dibagi menjadi tiga komponen, yaitu: Human Capital (HC), Structural Capital (SC), dan Capital Employed (Martin \& Hartley, 2006, h.23). Selanjutnya menurut (Bontis et al. 2000), secara sederhana HC mencerminkan individual knowledge stock suatu organisasi yang dipresentasikan oleh karyawannya

Adapun hipotesis pada penelitian ini adalah:

* Corresponding author's e-mail: ekarima@unpam.ac.id 
Jurnal Akuntansi Berkelanjutan Indonesia - Vol. 4, No. 2, Mei 2021 - Prasetya \& Oktavianna

H1: $\quad$ sales growth dan intellectual capital berpengaruh secara simultan terhadap financial distress.

$\mathrm{H} 2$ : $\quad$ sales growth berpengaruh terhadap financial distress.

$\mathrm{H} 3$ : $\quad$ intellectual capital berpengaruh terhadap financial distress

\section{METODE PENELITIAN}

Jenis penelitian ini adalah penelitian pendekatan kuantitatif, dengan menggunakan metode deskriptif. Data yang digunakan adalah data sekunder karena penelitian ini menggunakan data laporan keuangan perusahaan manufaktur yang terdaftar di Bursa Efek Indonesia yang dapat diakses melalui situs (www.idx.co.id) tahun 2014-2019.

\section{Teknik Pengumpulan data}

Penelitian ini mengambil data dengan cara mengakses situs (www.idx.co.id) dan memilih perusahaan manufaktur yang terdaftar di Bursa Efek Indonesia tahun 2014-2019. Dan ditambahkan dengan studi pustaka dari beberapa buku, penelitian terdahulu dan lainnya yang berhubungan dengan masalah dan tujuan penelitian.

\section{Operasional Variabel Penelitian}

Variabel dependen dalam penelitian ini adalah Financial distress sedangkan variabel independen dalam penelitian ini adalah sales growth dan intellectual capital.

Financial distress diukur dengan model Interest Coverage Ratio (ICR) :

$$
\text { Interest Coverage Ratio }(\mathrm{ICR})=\underline{\text { Laba sebelum bunga dan pajak }}
$$

Beban bunga

sales growth diukur dengan :

$$
\text { Pertumbuhan penjualan }=\frac{\text { Penjualan }_{t}-\text { Penjualan }_{t-1}}{\text { Penjualan }_{t-1}}
$$

Intellectual Capital diukur dengan Value Added Intellectual Coefficient (VAIC ${ }^{\text {TM})}$ yang dikembangkan oleh Pulic (1998; 1999; 2000). metode VAIC di mana terdapat 3 komponen untuk mengukur kinerja modal intelektual yaitu VAHU (Value Added Human Capital), VACA (Value Added Capital Employed) dan STVA (Structural Capital Value Added) (Ardalan \& Askarian, 2014). Dalam metode ini, nilai tambah diperoleh dari perbedaan antara input dengan output:

Keterangan:

* Corresponding author's e-mail: ekarima@unpam.ac.id 
Jurnal Akuntansi Berkelanjutan Indonesia - Vol. 4, No. 2, Mei 2021 - Prasetya \& Oktavianna

\section{Value Added = Output - Input}

Output (OUT) : : Total penjualan dan pendapatan lain;

Input (IN)

: Beban dan biaya-biaya (selain beban karyawan)

Value Added (VA) : Selisih antara Output dan Input

Berikut komponen dan cara pengukurannya dari ketiga komponen VAIC:

1. Capital Employed (Value Added Capital Employed)

$$
\mathrm{VACA}=\frac{\mathrm{VA}}{\mathrm{CE}}
$$

2. Human Capital (Value Added Human Capital)

$\mathrm{VAHU}=\frac{\mathrm{VA}}{\mathrm{HC}}$

3. Structural Capital (Structural Capital Value Added)

STVA $=\underline{\mathrm{SC}}$

$\overline{\mathrm{VA}}$

$\mathrm{VAIC}^{\mathrm{TM}}=\mathrm{VACA}+\mathrm{VAHU}+\mathrm{STVA}$

\section{Teknik Penentuan Sampel}

Populasi pada penelitian ini adalah perusahaan manufaktur yang masuk dalam Bursa Efek Indonesia Tahun 2014-2019. Teknik yang digunakan dalam penentuan sampel ini adalah purposive sampling. Dengan kriteria:

1. Perusahaan subsektor industri barang konsumsi yang terdaftar di Bursa Efek Indonesia secara berturut-turut tahun 2015-2019.

2. Perusahaan yang menerbitkan laporan keuangan selama periode 2015-2019, dan termasuk dalam subsektor industri barang konsumsi.

3. Laporan keuangan di laporkan selama periode 31 Desember setiap tahunnya selama 2015-2019, menggunakan Bahasa Indonesia dan satuan rupiah.

4. Perusahaan tidak memiliki kelengkapan data yang diperlukan untuk penelitian, di mana data tersebut diperoleh dari Annual Report

\section{Teknik Analisis Data}

Penelitian ini menggunakan teknik analisis kuantitatif dan perhitungannya menggunakan metode statistik yang dibantu dengan program eviews 10. Dengan beberapa tahapan: 
Jurnal Akuntansi Berkelanjutan Indonesia - Vol. 4, No. 2, Mei 2021 - Prasetya \& Oktavianna

1. Statistik deskriptif akan memberikan gambaran atau deskripsi umum dari variabel penelitian, yaitu mengenai central tendency yaitu nilai rata-rata (mean) dan ukuran dispersi yaitu standar deviasi, nilai maksimum dan nilai minimum.

2. Estimasi Model Regresi Data Panel. Terdapat tiga model yang dapat digunakan untuk melakukan regresi data panel. Ketiga model tersebut adalah Pooled OLS/ Common Effect, Fixed Effect dan Random Effect.

3. Pemilihan model regresi data panel untuk memilih model mana yang terbaik diantara ketiga model tersebut, yaitu dengan cara dilakukan uji Chow, uji Hausman, dan uji Lagrange Multiplier.

4. Uji asumsi klasik merupakan prasyarat analisis regresi data panel, yang meliputi Uji Normalitas, Uji Multikolinieritas, Uji Heteroskedastisitas dan Uji Autokorelasi.

5. Analisis Koefisien Determinasi. Koefisien determinasi (R2) pada dasarnya mengukur seberapa jauh kemampuan model dalam menerangkan variasi variabel dependen.

6. Analisis Regresi data panel, $\mathrm{Y}=\alpha+\mathrm{bXit}+\mathrm{e}$

di mana $\alpha$ : Konstanta

$\mathrm{X}$ : Variabel independen

$\beta$ : Koefisien regresi variabel independen

e: Error term

t: Waktu

i: Perusahaan

7. Uji hipotesis

4. ANALISIS DATA DAN PEMBAHASAN

Pemilihan Model Regresi Data Panel

Uji Chow

Tabel 1. Uji Chow

\begin{tabular}{|c|c|c|c|}
\hline Effects Test & Statistic & d.f. & Prob. \\
\hline Cross-section F & 27.878454 & $(13,68)$ & 0.0000 \\
\hline Cross-section Chi-square & 155.001298 & 13 & 0.0000 \\
\hline
\end{tabular}

Nilai probabilitas $\mathrm{F}<0,05$ sehingga model yang sesuai dari hasil Uji Chow yaitu fixed effects

* Corresponding author's e-mail: ekarima@unpam.ac.id 
Jurnal Akuntansi Berkelanjutan Indonesia - Vol. 4, No. 2, Mei 2021 - Prasetya \& Oktavianna

\section{Uji Hausman}

\section{Tabel 2. Uji Hausman}

Correlated Random Effects - Hausman Test

Equation: Untitled

Test cross-section random effects

\begin{tabular}{llrr}
\hline \hline Test Summary & \multicolumn{1}{c}{$\begin{array}{l}\text { Chi-Sq. } \\
\text { Statistic }\end{array}$} & Chi-Sq. d.f. & Prob. \\
\hline \hline Cross-section random & 11.750946 & 2 & 0.0028 \\
\hline
\end{tabular}

Nilai probabilitas yaitu $<0,05$ maka metode yang kita pilih adalah fixed effect.

\section{Uji Asumsi Klasik}

\section{Uji normalitas}

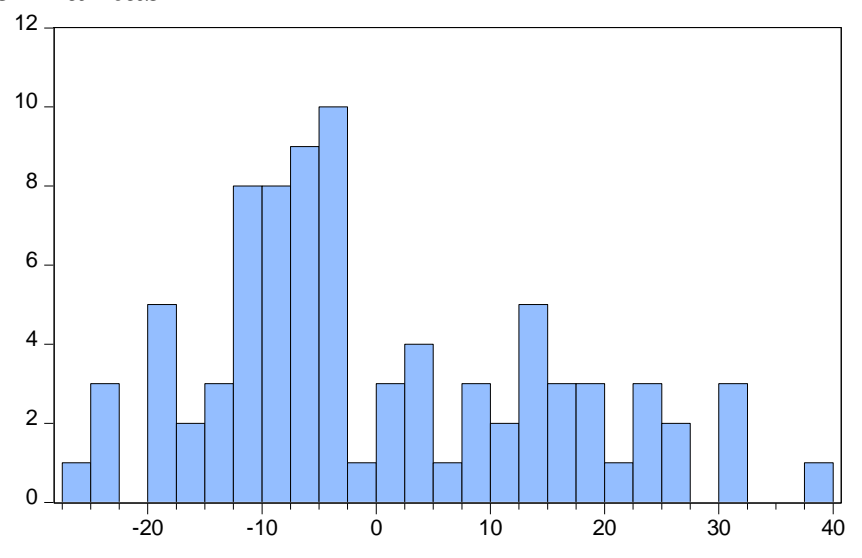

\begin{tabular}{ll}
\hline Series: Standardized Residuals \\
Sample 2014 2019 \\
Observations 84 \\
Mean & $-5.08 \mathrm{e}-16$ \\
Median & -4.313422 \\
Maximum & 38.06107 \\
Minimum & -26.02142 \\
Std. Dev. & 15.19398 \\
Skewness & 0.561089 \\
Kurtosis & 2.464715 \\
& \\
Jarque-Bera & 5.410350 \\
Probability & 0.066859
\end{tabular}

\section{Gambar 1. Uji Normalitas}

Nilai Jarque-Bera dan Probabilitynya 0.066859> 0.05, maka tidak menolak H0 atau residual mempunyai distribusi normal 
Jurnal Akuntansi Berkelanjutan Indonesia - Vol. 4, No. 2, Mei 2021 - Prasetya \& Oktavianna

\section{Uji Heterokedasitas}

\section{Tabel 3. Uji Heterokedasitas}

\begin{tabular}{|c|c|c|c|c|}
\hline $\begin{array}{l}\text { Dependent Vari } \\
\text { Method: Panel } \\
\text { Date: } 04 / 16 / 21 \\
\text { Sample: } 20142 \\
\text { Periods includec } \\
\text { Cross-sections i } \\
\text { Total panel (bal } \\
\text { Linear estimatio }\end{array}$ & $\begin{array}{l}\text { ded: } 14 \\
\text { d) observatio } \\
\text { ter one-step }\end{array}$ & on weights) & & \\
\hline Variable & Coefficient & Std. Error & t-Statistic & Prob. \\
\hline $\mathrm{X} 1$ & -2.390072 & 3.442762 & -0.694231 & 0.4899 \\
\hline $\mathrm{X} 2$ & -0.648575 & 0.639044 & -1.014915 & 0.3137 \\
\hline $\mathrm{C}$ & 14.62831 & 3.277009 & 4.463923 & 0.0000 \\
\hline
\end{tabular}

Hasil dari probalititas data resudial absolutenya menunjukan $>0.05$, artinya tidak terjadi heterokedasitas.

\section{Uji Multikolinearitas}

Tabel 4. Uji Multikolinearitas

\begin{tabular}{lrr}
\hline & sales growth & \multicolumn{1}{c}{ intellectual capital } \\
\hline sales growth & 1 & 0.03427820015586512 \\
intellectual capital & 0.03427820015586512 & 1 \\
\hline
\end{tabular}

Nilai korelasi dari masing-masing variabel bebas $<0,85$ maka tidak menolak H0 atau tidak terjadi masalah multikolinieritas

Tabel 5. Uji Autokorelasi

\begin{tabular}{llll}
\hline \hline Cross-section fixed (dummy variables) & \\
\hline \hline & \multicolumn{2}{l}{ Weighted Statistics } & \\
\hline \hline R-squared & 0.920670 & Mean dependent var & 65.77704 \\
Adjusted R-squared & 0.903171 & S.D. dependent var & 63.87250 \\
S.E. of regression & 16.78634 & Sum squared resid & 19161.12 \\
F-statistic & 52.61228 & Durbin-Watson stat & 1.672237 \\
Prob(F-statistic) & 0.000000 & & \\
\hline \hline
\end{tabular}

Tidak terjadi autokorelasi karena nilai DW : 1.672237 berada diantara -2 dan +2 atau $-2<$ DW $<+2$.

* Corresponding author's e-mail: ekarima@unpam.ac.id 
Jurnal Akuntansi Berkelanjutan Indonesia - Vol. 4, No. 2, Mei 2021 - Prasetya \& Oktavianna

\section{Uji Hipotesis}

\section{Tabel 6. Uji Regresi}

Dependent Variable: Y

Method: Panel EGLS (Cross-section weights)

Date: 04/16/21 Time: 22:41

Sample: 20142019

Periods included: 6

Cross-sections included: 14

Total panel (balanced) observations: 84

Linear estimation after one-step weighting matrix

\begin{tabular}{crrrr}
\hline \hline Variable & Coefficient & Std. Error & t-Statistic & Prob. \\
\hline \hline C & -4.873638 & 7.603377 & -0.640983 & 0.5237 \\
X1 & -3.525905 & 7.638004 & -0.461627 & 0.6458 \\
X2 & 10.26958 & 1.497253 & 6.858948 & 0.0000 \\
\hline \hline
\end{tabular}

Cross-section fixed (dummy variables)

\begin{tabular}{llll}
\hline \hline & \multicolumn{2}{l}{ Weighted Statistics } & \\
\hline \hline R-squared & 0.920670 & Mean dependent var & 65.77704 \\
Adjusted R-squared & 0.903171 & S.D. dependent var & 63.87250 \\
S.E. of regression & 16.78634 & Sum squared resid & 19161.12 \\
F-statistic & 52.61228 & Durbin-Watson stat & 1.672237 \\
Prob(F-statistic) & 0.000000 & & \\
\hline \hline & Unweighted Statistics & \\
\hline \hline & 0.842545 & Mean dependent var & 44.71554 \\
R-squared & 20861.30 & Durbin-Watson stat & 1.647739 \\
\hline \hline
\end{tabular}

Hasil uji regresi estimasi fixed effect, maka model regresi data panelnya yaitu:

$$
\mathrm{Y}=-4.873638+-3.525905 \mathrm{X} 1+10.26958 \mathrm{X} 2+\mathrm{e}
$$

1. Nilai konstanta dari hasil model regresi data panel sebesar -4.873638 . Jika Sales growth dan Intellectual Capital bernilai nol, maka besarnya Financial distress sebesar -4.873638 .

2. Nilai Koefisien pada model regresi data panel yaitu -3.525905 untuk Sales growth dan 10.26958 untuk Intellectual Capital jadi jika terdapat kenaikan satu pada variabel Sales growth maka nilai Financial distress akan mengurangi sebesar -3.525905 dan jika ada kenaikan satu pada variabel Intellectual Capital maka akan meningkatkan nilai Financial distress sebesar 10.26958 
Jurnal Akuntansi Berkelanjutan Indonesia - Vol. 4, No. 2, Mei 2021 - Prasetya \& Oktavianna

3. Dari nilai Prob(F-statistic) $0.000000<0.005$, menujukkan Sales growth dan Intellectual Capital memiliki pengaruh secara simultan signifikan terhadap Financial distress

4. Dari hasil penelitian yang ditunjukkan nilai Sales growth variabel independen (X1) 0.6458> 0,05, maka berarti variabel Sales growth tidak berpengaruh terhadap Financial distress. Namun pada nilai Intellectual Capital (X2) menunjukkan $0.0000<0.05$, maka variabel firm size berpengaruh terhadap Financial distress.

5. Nilai koefisien determinasinya dalam penelitian ini adalah 0.920670 atau 92 $\%$. Sehingga dapat di simpulkan $92 \%$ Financial distress dipengaruhi oleh Sales growth dan Intellectual Capital, sedangkan sisanya sebesar $8 \%$ dipengaruhi oleh variabel lain

\section{Pengaruh Sales growth dan Intellectual Capital terhadap Financial distress}

Berdasarkan hasil uji regresi diketahui bahwa Sales growth dan Intellectual Capital memiliki pengaruh secara simultan signifikan terhadap Financial Distress. Hal ini menunjukkan semakin besar atau tingginya Sales Growth dan Intellectual Capital akan sangat berperan dalam mempengaruhi keadaan financial suatu perusahaan.

\section{Pengaruh Sales growth terhadap Financial distress}

Berdasarkan hasil uji regresi diketahui bahwa Sales Growth tidak memiliki pengaruh terhadap Financial Distress. Hal ini dikarenakan tingginya tingkat Sales Growth tidak selalu memiliki beban yang sedikit sedikit, sehingga laba bersih yang dihasilkan hanya sedikit atau tidak mencapai target bahkan bisa negative, hal tersebut dapat berdampak terhadap kondisi keuangan perusahaan yang dapat memungkinkan terjadinya Financial Distress di masa mendatang. Penelitian ini sejalan dengan penelitian ( Rahmy, 2015; Prasetya, 2021; Dianova, 2019; dan Giarto ; 2020 ) yang menyatakan bahwa sales growth tidak berpengaruh terhadap Financial Distress. Hasil penelitian Amanda (2019) menyatakan hasil yang berbeda yakni sales growth berpengaruh terhadap Financial Distress.

\section{Pengaruh Intellectual Capital terhadap Financial distress}

Berdasarkan hasil uji regresi diketahui bahwa Intellectual Capital memiliki pengaruh terhadap Financial Distress. Semakin besar tingkat intellectual capital maka akan menciptakan nilai dan keberhasilan bagi perusahaan tersebut. Hal ini berarti bahwa perusahaan memiliki manajemen dan sumber daya yang berkemampuan lebih baik sehingga kecil risikonya bagi perusahaan terindikasi financial distress. Penelitian ini sejalan dengan penelitian oleh (Mustika et al, 2018; Ardalan, 2014; Anggraini, 2020; dan Mulyatiningsih; 2021) yang mengatakan bahwa intellectual capital memiliki pengaruh signifikan terhadap Financial Distress. 
Jurnal Akuntansi Berkelanjutan Indonesia - Vol. 4, No. 2, Mei 2021 - Prasetya \& Oktavianna

\section{KESIMPULAN DAN SARAN}

Penelitian ini bertujuan untuk mengetahui pengaruh Sales Growth dan Intellectual Capital terhadap Financial distress pada perusahaan manufaktur yang terdaftar di Bursa Efek Indonesia periode 2014-2019. Jumlah sampel dalam penelitian ini yaitu 84 sampel. Hasil analisis regresi data panel disimpulkan bahwa Sales growth dan Intellectual Capital secara simultan berpengaruh terhadap Financial Distress. Sales Growth tidak berpengaruh terhadap Financial Distress dan Intellectual Capital berpengaruh terhadap Financial Distress.

Sebaiknya perusahaan memperhatikan pertumbuhan penjualan meskipun pertumbuhan penjualan tidak bisa di jadikan penilaian dari keadaan kesulitan keuangan dari sebuah perusahaan. Faktor lainnya yang bisa mempengaruhi kesulitan keuangan perusahaan sebaiknya diteliti oleh peneliti selanjutnya.

\section{DAFTAR PUSTAKA}

Anggraini, F., Seprijon, Y. P., \& Rahmi, S. (2020). Pengaruh Intellectual Capital Terhadap Nilai Perusahaan Dengan Financial Distress Sebagai Variabel Intervening. Jurnal Informasi, Perpajakan, Akuntansi, Dan Keuangan Publik, 15(2), 169-190.

Amanda, Y., \& Tasman, A. (2019). Pengaruh Likuiditas, Leverage, Sales Growth dan Ukuran Perusahaan Terhadap Financial Distress Pada Perusahaan Manufaktur yang Terdaftar di Bursa Efek Indonesia (BEI) Periode 20152017. Jurnal Ecogen, 2(3), 453-462.

Bontis, N., W. C. C. Keow and S. Richardson (2000), 'Intellectual capital and business performance in Malaysian industries', Journal of Intellectual Capital, 1(1), pp. 85-100.

Dianova, A., \& Nahumury, J. (2019). Investigating the Effect of Liquidity, Leverage, Sales Growth and Good Corporate Governance on Financial Distress. Journal of Accounting and strategic Finance, 2(2), 143-156.

Giarto, R. V. D., \& Fachrurrozie, F. (2020). The Effect of Leverage, Sales Growth, Cash Flow on Financial Distress with Corporate Governance as a Moderating Variable. Accounting Analysis Journal, 9(1), 15-21.

Hidayat, Muhammad Arif (2013). Prediksi Financial Distress Perusahaan Manufaktur di Indonesia (Studi Empiris pada Perusahaan Manufaktur yang Terdaftar di Bursa Efek Indonesia Periode 2008- 2012). Skripsi. Fakultas Ekonomika dan Bisnis, Universitas Diponegoro.

* Corresponding author's e-mail: ekarima@unpam.ac.id http://openjournal.unpam.ac.id/index.php/JABI 
Jurnal Akuntansi Berkelanjutan Indonesia - Vol. 4, No. 2, Mei 2021 - Prasetya \& Oktavianna

Hadi, S. (2014). Mekanisme Corporate Governance, Likuiditas, Leverage, dan Operating Capacity pada Perusahaan yang Mengalami Financial Distress.

Hanifah, O. E., \& Purwanto, A. (2013). Pengaruh Struktur Corporate Governance dan Financial Indicators terhadap kondisi financial Distress (Studi pada perusahaan manufaktur yang terdaftar di Bursa Efek Indonesia Periode 2009-2011) (Doctoral dissertation, Fakultas Ekonomika dan Bisnis).

Hapsari, E. I. (2012). Kekuatan rasio keuangan dalam memprediksi kondisi financial distress perusahaan manufaktur di BEI. JDM (Jurnal Dinamika Manajemen), 3(2).

Harahap, Syofyan Syahri. 2013. Analisis atas Laporan Keuangan. Jakarta: Raja Grafindo Persada.

Irawati, W. (2018). The Effect of Free Cash Flow, Size, and Growth with Profitability as Moderating Variable on Earning Response Coefficient in Property Sector. EAJ (Economic and Accounting Journal), 1(1), 76-86.

Maihafni.(2016). Pengaruh Aset Tetap Tak Berwujud terhadap Financial Distress. Tanjung Pinang: Universitas Maritim Raja Ali Haji

Martin, Chris \& Hartley, Julie. 2006. SME intangible assets, Certified Accountants Educational Trust. London, Research Report No. 93.

Mulyatiningsih, N., \& Atiningsih, S. (2021). PERAN PROFITABILITAS DALAM MEMODERASI PENGARUH INTELLECTUAL CAPITAL, LEVERAGE, DAN SALES GROWTH TERHADAP FINANCIAL DISTRESS. Jurnal Riset Akuntansi (JUARA), 11(1), 55-74.

Puspitasari, E., \& Srimindarti, C. (2014). Peran Indikator Kekayaan Intelektual Terhadap Kinerja Perusahaan Pada Perusahaan Manufaktur Yang Terdaftar Di Bursa Efek Indonesia. Jurnal Organisasi dan Manajemen, 10(1), 59-77.

Prasetya, E. R., \& Putri, W. C. (2021, January). FINANCIAL DISTRESS SEBAGAI DAMPAK DARI OPERATING CAPACITY, SALES GROWTH DAN RASIO LIKUIDITAS PADA SEKTOR INDUSTRI BARANG KONSUMSI DI INDONESIA TAHUN 2016-2018. In PROSIDING SENANTIAS: Seminar Nasional Hasil Penelitian dan Pengabdian kepada Masyarakat (Vol. 1, No. 1, pp. 899-908).

Pulic, A. (1998), "Measuring the performance of intellectual potential in knowledge economy", available at: www.measuringip.at/Opapers/Pulic/Vaictxt.vaictxt.html (accessed 11 March, 2003).

Pulic, A. (2000), "An accounting tool for IC management", available at: www.measuring-ip.at/ Papers/ham99txt.htm (accessed 11 March, 2003).

* Corresponding author's e-mail: ekarima@unpam.ac.id http://openjournal.unpam.ac.id/index.php/JABI 
Jurnal Akuntansi Berkelanjutan Indonesia - Vol. 4, No. 2, Mei 2021 - Prasetya \& Oktavianna

Pulic, A. and Bornemann, M. (1999). The physical and intellectual capital of Austrian banks. available at: www.measuring-ip.at/Papers/Pubic/Bank/enbank.html (accessed 11 March, 2003).

Rahmy, R. (2015). Pengaruh Profitabilitas, Financial Leverage, Sales Growth Dan Aktivitas Terhadap Financial Distress (Studi Empiris pada Perusahaan Manufaktur yang Terdaftar di BEI Tahun 2009-2012). Jurnal Akuntansi, 3(1).

Rohmadini, A., Saifi, M., \& Darmawan, A. (2018). Pengaruh Profitabilitas, Likuiditas Dan Leverage Terhadap Financial Distress (Studi Pada Perusahaan Food \& Beverage Yang Terdaftar Di Bursa Efek Indonesia Periode 2013-2016). Jurnal Administrasi Bisnis, 61(2), 11-19.

Safitri, I., Triana, S. R., Siregar, S. I., \& Prasetya, E. R. (2020). PENGARUH KEBIJAKAN UTANG DAN AGRESIVITAS TERHADAP NILAI PERUSAHAAN (Studi empiris pada perusahaan manufaktur sektor industri barang konsumsi yang terdaftar di bei periode 20142018). PROCEEDINGS UNIVERSITAS PAMULANG, 1(1), 146-157.

Whidiari,N.,L.,M.,A. \& Merkusiwati,N.,L.,A., (2015). Pengaruh Rasio Likuiditas, Leverage, Operating Capacity, Dan Sales Growth Terhadap Financial Distress. E-Jurnal Akuntansi Universitas Udayana 11.2 (2015): 456-469 